Article

\title{
Viability of Anisakis spp. Larvae After Direct Exposure to Different Processing Media and Non-Thermal Processing in Anchovy Fillets
}

\author{
Vida Šimat* $*$ and Željka Trumbić \\ University Department of Marine Studies, University of Split, Ruđera Boškovića 37, 21000 Split, Croatia; \\ ztrumbic@unist.hr \\ * Correspondence: vida@unist.hr; Tel.: +38-521-510-192
}

Received: 5 February 2019; Accepted: 7 March 2019; Published: 13 March 2019

check for updates

\begin{abstract}
Anisakiasis is fish-borne zoonoses caused by nematodes of the genus Anisakis, contracted by the ingestion of live L3 infective larvae through consumption of raw, undercooked or thermally unprocessed seafood products, such as carpaccio, and white marinated and dry-salted anchovies. In order to maintain the organoleptic properties of the product, the freezing of fish prior to processing is often ignored, especially in households, and traditional processing methods are not sufficient to kill Anisakis larvae. In this study, we investigated the survival and resistance of Anisakis spp. larvae in different processing solutions including varying salt and sugar content, lemon juice, acetic acid, alcohol, wine, and apple vinegar. We also performed a viability test of larvae during processing in anchovy fillets. When exposed directly to different $\mathrm{NaCl}$ concentrations, larvae were killed after approximately three days in the strongest (35\%) and 10 days in the weakest solution (5\%). In lemon juice and lemon juice with added acetic acid, the survival of larvae was around 5 days. In intact alcohol vinegar, larvae were killed under less than $48 \mathrm{~h}$, while in the solution with water their resistance was prolonged to almost 40 days. In fillets, larvae showed increased resistance during carpaccio and white wine vinegar marinades and only dry salting was effective in destroying Anisakis spp. larvae.
\end{abstract}

Keywords: Anisakis spp.; viability; Engraulis encrasicolus; carpaccio; marinade; dried salting; lemon juice; sugar

\section{Introduction}

Anisakiasis is a fish-borne zoonoses caused by nematode parasites of the genus Anisakis. It is contracted by the ingestion of live L3 infective larvae through consumption of raw, undercooked or thermally unprocessed (smoked, salted, marinated) fish or cephalopod products, and it is considered an emerging human disease. The first records of human anisakiasis probably date back to Greenland in 1876 [1] and the Netherlands in the 1960s [2], and have become increasingly widespread since then with $>20,000$ cases reported worldwide, most deriving from Japan [1,3], with Spain and Italy showing significant prevalence among European countries [4-7]. A recent multicriteria prioritization study of food-borne parasites ranked Anisakidae in the first ten for all European regions and 17th globally [8], presumably correlated with better medical diagnostics, as well as current dynamic ecological and societal changes in the world, including frequent travelling, globalization, changing of dietary habits, and higher demand for fish protein and/or raw/undercooked products, especially with younger generations, as well as climate change [9]. Humans are an unintentional or accidental host to Anisakis, transferred from paratenic hosts that serve as transmissible vectors to final hosts, marine mammals. Anisakiasis can adopt invasive or non-invasive aspects, depending on whether larvae are able to 
penetrate gastrointestinal mucosae upon ingestion [6]. The symptoms may or may not include severe gastrointestinal symptoms such as epigastralgia, nausea, vomiting, and abdominal pain or allergic manifestations ranging from urticaria and angioedema to anaphylactic shock, in which case the patients become sensitized to Anisakis allergens and are at risk of allergic episodes upon exposure to the worm, ingested dead or alive $[3,10]$. Currently, there are nine species recognized in the genus Anisakis, of which A. simplex (sensu stricto) and A. pegreffii have been proven etiological agents of human anisakiasis [6]. Studies have suggested these two species show different immunopathogenic potential to humans and tolerance to environmental conditions; however, they both remain pathogenic and are a potential threat to human health [11-13].

In promotion of healthy living, dietary habits and food preferences are changing worldwide, with raw, undercooked, and traditionally prepared fish becoming extremely popular, such as carpaccio (fish marinated in lemon juice); ceviche (fish and spices marinated in lime juice); lomi lomi (salmon marinated in lemon juice, onion and tomato); poisson cru (fish marinated in citrus juice, onion, tomato and coconut milk); sashimi (slices of raw fish); sushi (pieces of raw fish with rice and other ingredients); green herring (lightly brined herring); cold-smoked fish, and undercooked grilled fish. The traditional Mediterranean diet features minimally processed seafood products, specifically traditional carpaccio-like products (cold-marinated fish in fruit juice, citric acid, and salt), white marinated anchovies (marinate in vinegar and salt), and dry-salted anchovies. Anchovies are characterized by a gentler texture and relatively lower fat content [14], which makes them good raw material for minimally processed fish products. However, many traditional processing technologies such as cold marinating, brining, and cold-smoking methods are not sufficient to kill Anisakis larvae. In accordance with health guidelines, preventive programs and measures in the frame of European Commission (EC) regulations 853/2004 and 1276/2011 require obligate freezing of the fish at a temperature of not more than $-20^{\circ} \mathrm{C}$ for $24 \mathrm{~h}$ prior to such industrial processes $[15,16]$. Food businesses regulate their production according to EC standards and ensure visual examination to avoid placing contaminated products with parasites on the market. Freezing, however, affects the texture and protein structure of the fish muscle, thus adopting the marinating process to thawed fish results in a product/dish of lower quality in terms of sensory and textural properties, making the final product less attractive to the consumer. For this reason, restaurants and households often ignore the freezing recommendation and conduct only visual inspection of the fish products incurring substantial risk from anisakiasis.

European anchovy (Engraulis encrasicolus, L.), a small pelagic fish, widely spread in the Mediterranean, has an important economic value and it is a principal targeted species for commercial fisheries in Europe and one of the most attractive Mediterranean fisheries products [17,18]. Anchovies have a very important role in the preparation of traditional raw dishes that have already been associated with the onset of anisakiasis or food allergy in Italy, Spain, and Croatia [1,4,5,7,19-21], congruent with reports of the high prevalence of A. pegreffii in European anchovy in Central and South Adriatic (80\%), especially the Italian coast, compared to the rest of the Mediterranean Sea [17,18,22,23]. Most of the larvae are found on the visceral surface of the gastrointestinal tract and to a much lesser extent embedded in fillets $[17,18]$; however, Šimat et al. showed that $A$. pegreffii larvae persist in anchovy fillets of live fish and that post-mortem migration during storage at both 0 and $4{ }^{\circ} \mathrm{C}$ is delayed by $3-5$ days but still presumptive [22]. A recent study found significant numbers of dead Anisakis larvae in ready-to-eat products made of anchovies on the Italian market, which in addition to posing health risks for sensitized consumers, also represents extremely unpleasant experiences and can inflict economic losses [24].

The preservative effect of cold-marinating processes and dry salting as two of the oldest chemical preservation methods is achieved through the synergic effect of organic acids and salt, and high salt content, respectively. Croatian seafood products, such as dry, salted, and marinated anchovies, are exported to other EU members and wildly consumed as a delicacy in many Mediterranean countries. As an important tourist destination, Croatian traditional food may present a vehicle of anisakiasis 
to both local populations and foreign visitors. An important element of proper risk evaluation for consumer safety, management, and mitigation is the information on the viability of Anisakis larvae during processing [4]. Although the inactivation of Anisakis spp. larvae by chemical treatments was observed in several studies and larvae showed high sensitivity to salt content, different brines and marinade baths under certain conditions [1,25-27], the effect of all active ingredients of the marinade such as brines, different types of vinegars, lemon juices, wines, soy sauces, or the effect of different spices and plant extracts on their viability was not investigated. For this reason, we investigated the survival and resistance of Anisakis spp. larvae in following solutions: (i) 5, 10, 15, 20 and $35 \mathrm{~g}$ $\mathrm{NaCl} / 100 \mathrm{~mL}$ water; (ii) $10 \mathrm{~g}$ sugar/100 mL water; (iii) fresh lemon juice; (iv) lemon juice with addition of 5, 10, and 15\% acetic acid (vol/vol); (v) alcohol, wine, and apple vinegar; and (vi) alcohol, wine and apple vinegar solutions prepared with water in ratio 1:1. These brines and solutions are used in the production of carpaccio-like products, white marinated anchovies, and dry-salted anchovies, thus, we also performed the viability test of larvae during these three non-thermal processes in anchovy fillets.

\section{Results and Discussion}

\subsection{Viability of Larvae in Different Processing Media}

The viability of Anisakis spp. larvae in different processing media recorded in our study is shown in Figures 1-4. When exposed directly to different $\mathrm{NaCl}$ solutions (5, 10, 15, 20, and $35 \mathrm{~g} / 100 \mathrm{~mL})$, larvae were killed after approximately three days in the strongest and 10 days in the weakest solution (Figure 1). Stronger $\mathrm{NaCl}$ solution resulting in higher osmotic stress resulted in shorter larval survival in comparison to osmotic stress induced by sugar solution, which showed poor larvicidal capabilities (Figure 2). In this study, both 10 and $20 \mathrm{~g} / 100 \mathrm{~mL}$ (w/vol) sugar solutions were investigated, but there was no significant difference between them, thus only data for Anisakis viability in $10 \mathrm{~g} / 100 \mathrm{~mL}$ are shown (Figure 2). The Viability of anisakid larvae in brine can vary, i.e., in salted herring A. simplex larvae lived $>17$ weeks at $5 \% \mathrm{NaCl}$ and 6 weeks when $\mathrm{NaCl}$ content was 8-9\% [25]. In our study, the effect of brine was three times stronger, and after direct exposure $50 \%$ of Anisakis spp. larvae were dead after 2.5 days at a similar concentration. Although we have identified only a small proportion of larvae at the molecular level using partial mitochondrial COX2 DNA sequence as Anisakis pegreffii, and this species is most often found in the Adriatic Sea [28], due to a large number of larvae used in this study (>9000) not all samples were identified. Thus, we cannot say for certain that all larvae were A. pegreffii nor preclude the existence of hybrid genotypes that cannot be identified with mitochondrial marker alone. Nevertheless, interspecific differences between nematodes could account partially for observed differences in sensibility during brine treatment. Some Anisakis larvae are quite resistant to processing media such as brines and organic acid solutions, where they can live for weeks [25]. On the other hand, in lemon juice and lemon juice with added acetic acid, the survival of larvae was around 5 days (Figure 2). The addition of 10 and $15 \%$ of acetic acid to fresh lemon juice did not much influence the viability of the larvae. Sánchez-Monsalvez et al. directly exposed live anisakid larvae to different solutions containing concentrations of acetic acid (6-16\%, vol/vol in steps of $2 \%$ ) and 3 or $6 \%$ (wt/vol) of salt [26]. The authors recorded these concentrations of acetic acid and salt within the range found in the tissue of anchovies prepared in marinades containing 10 to $40 \%$ acetic acid. Death rates of the larvae were directly related to the concentrations of acetic acid and salt and ranged from $>10$ days in a solution containing $6 \%$ acetic acid and $3 \%$ salt to $<1$ day for larvae containing $>10 \%$ acetic acid and $6 \%$ salt. 


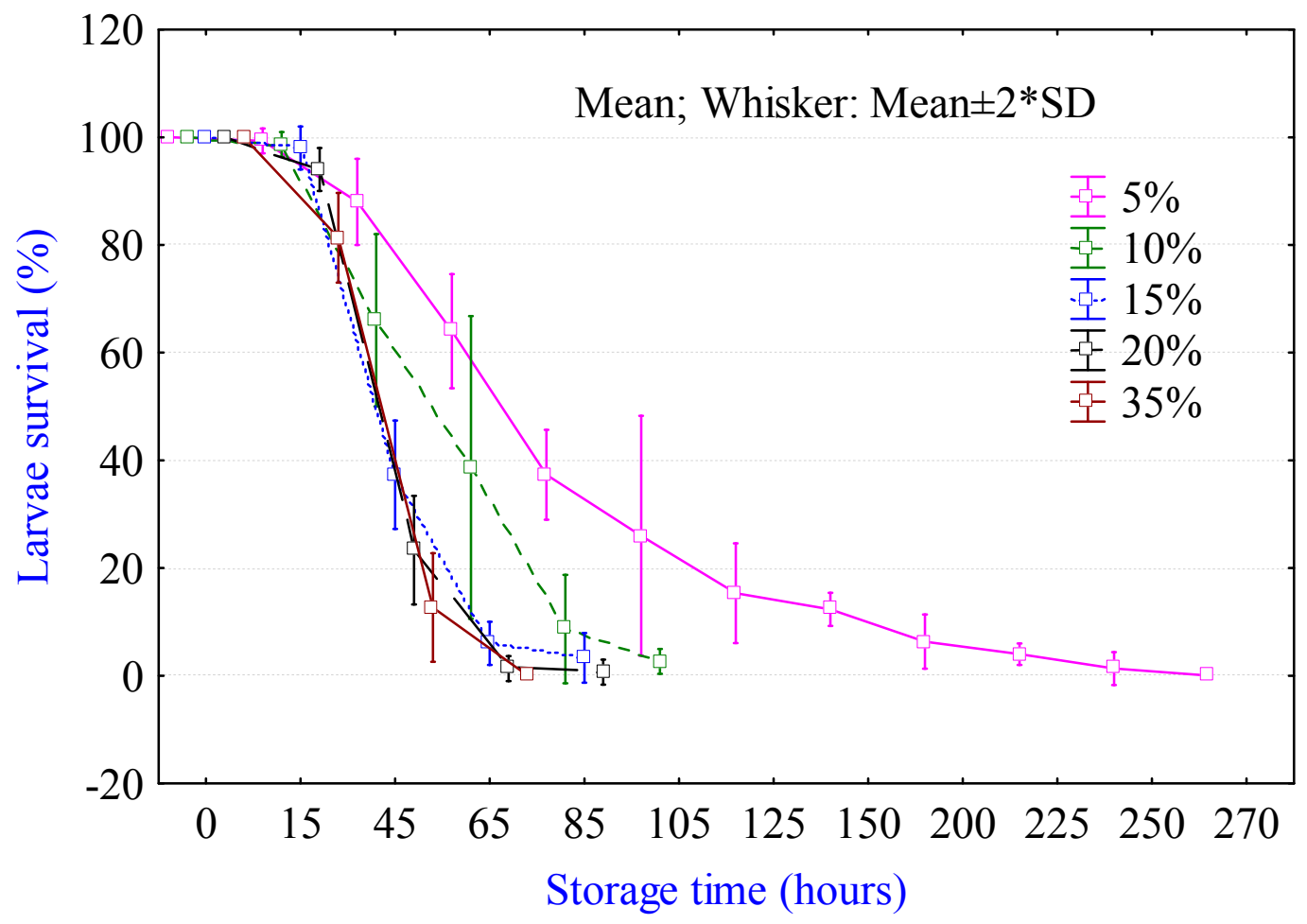

Figure 1. Survival of Anisakis spp. larvae exposed directly to different $\mathrm{NaCl}$ solutions $(5,10,15,20$, and $35 \mathrm{~g} / 100 \mathrm{~mL})$.

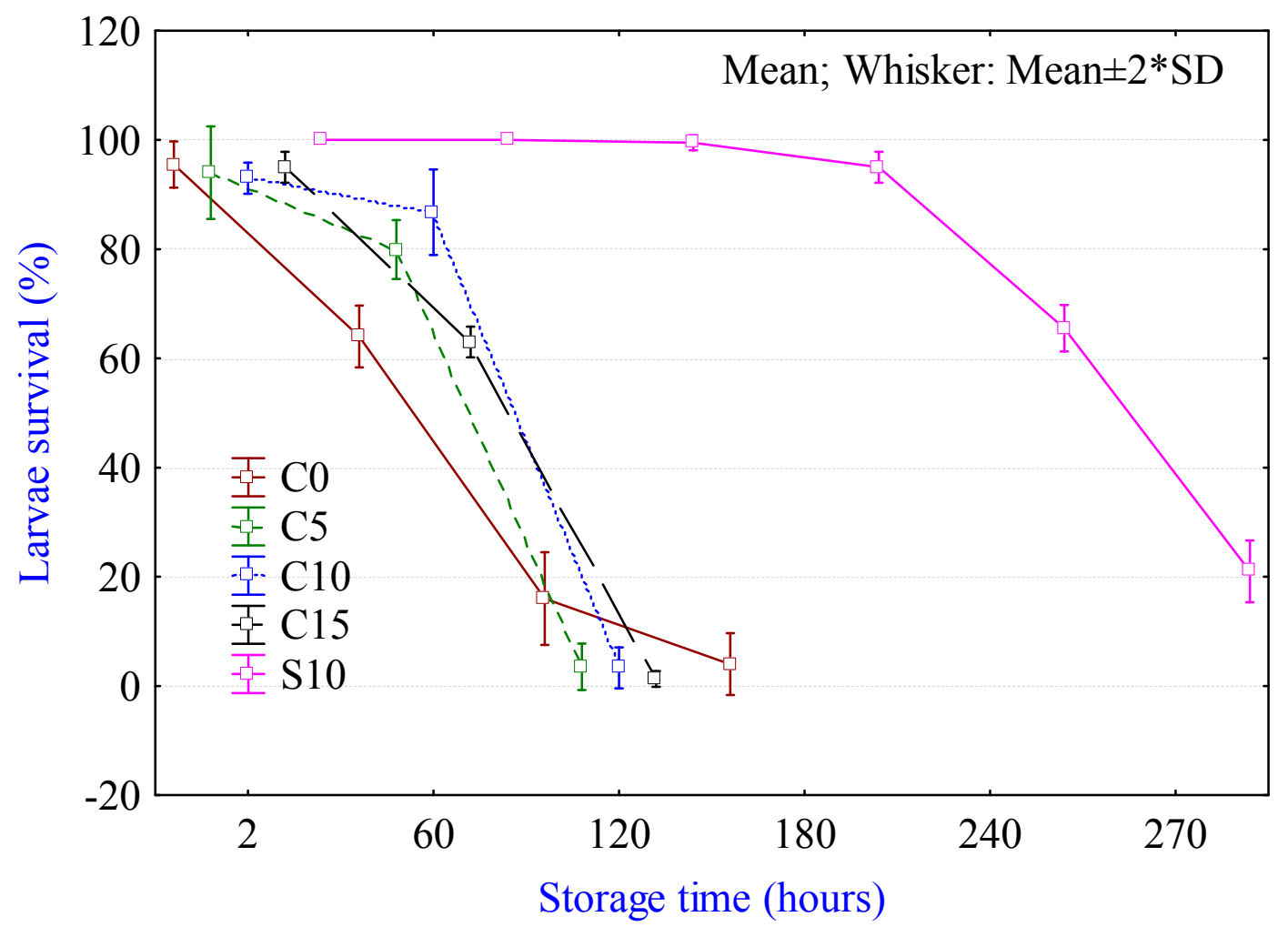

Figure 2. Survival of Anisakis spp. larvae exposed directly to fresh lemon juice (C0), lemon juice with addition of 5, 10, and 15\% vol/vol acetic acid (C5, C10, and C15); and sugar solution (S10, $10 \mathrm{~g} / 100 \mathrm{~mL})$. 


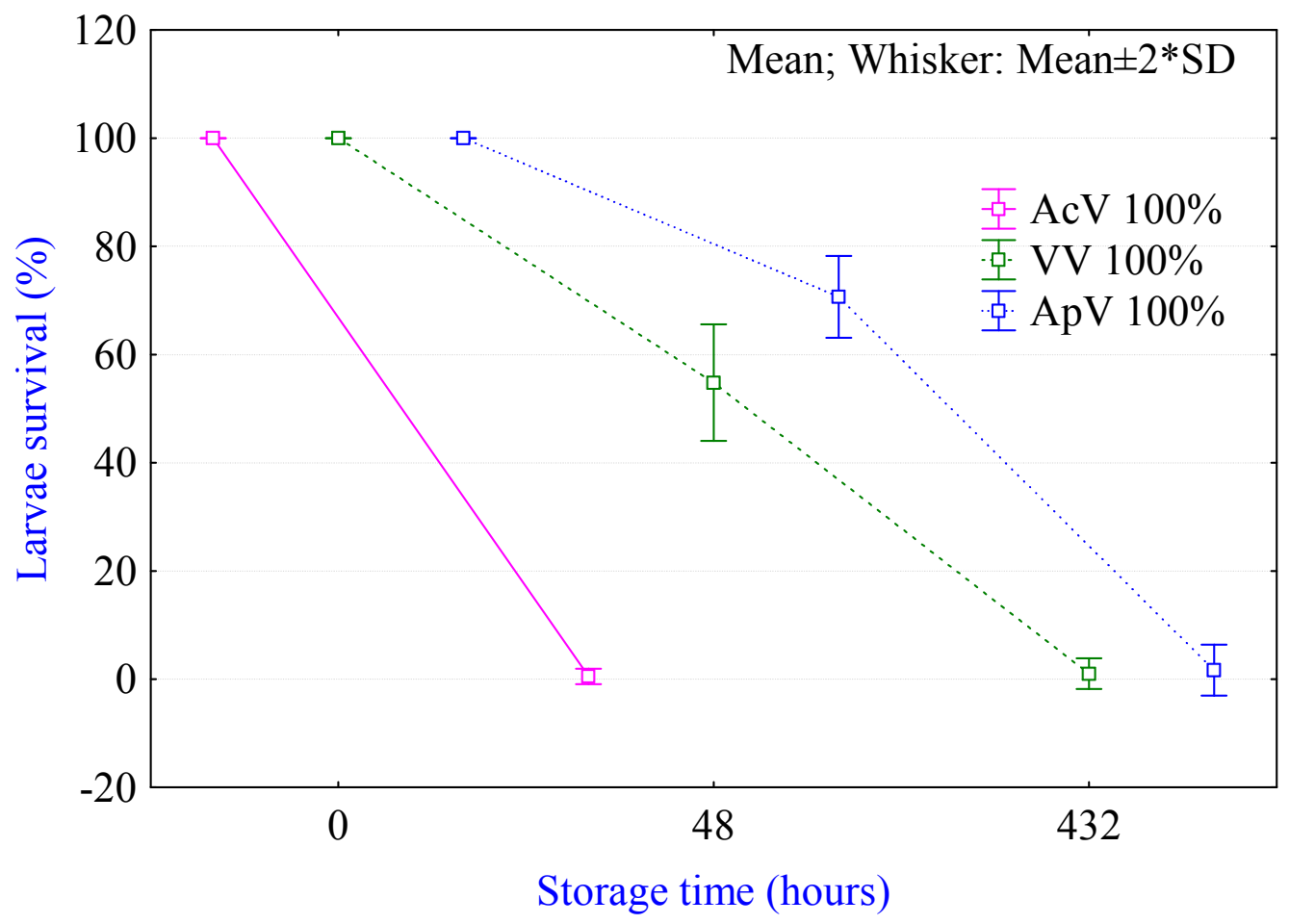

Figure 3. Survival of Anisakis spp. larvae exposed directly to alcohol (AcV 100\%), wine (VV 100\%) and apple vinegar (ApV 100\%).

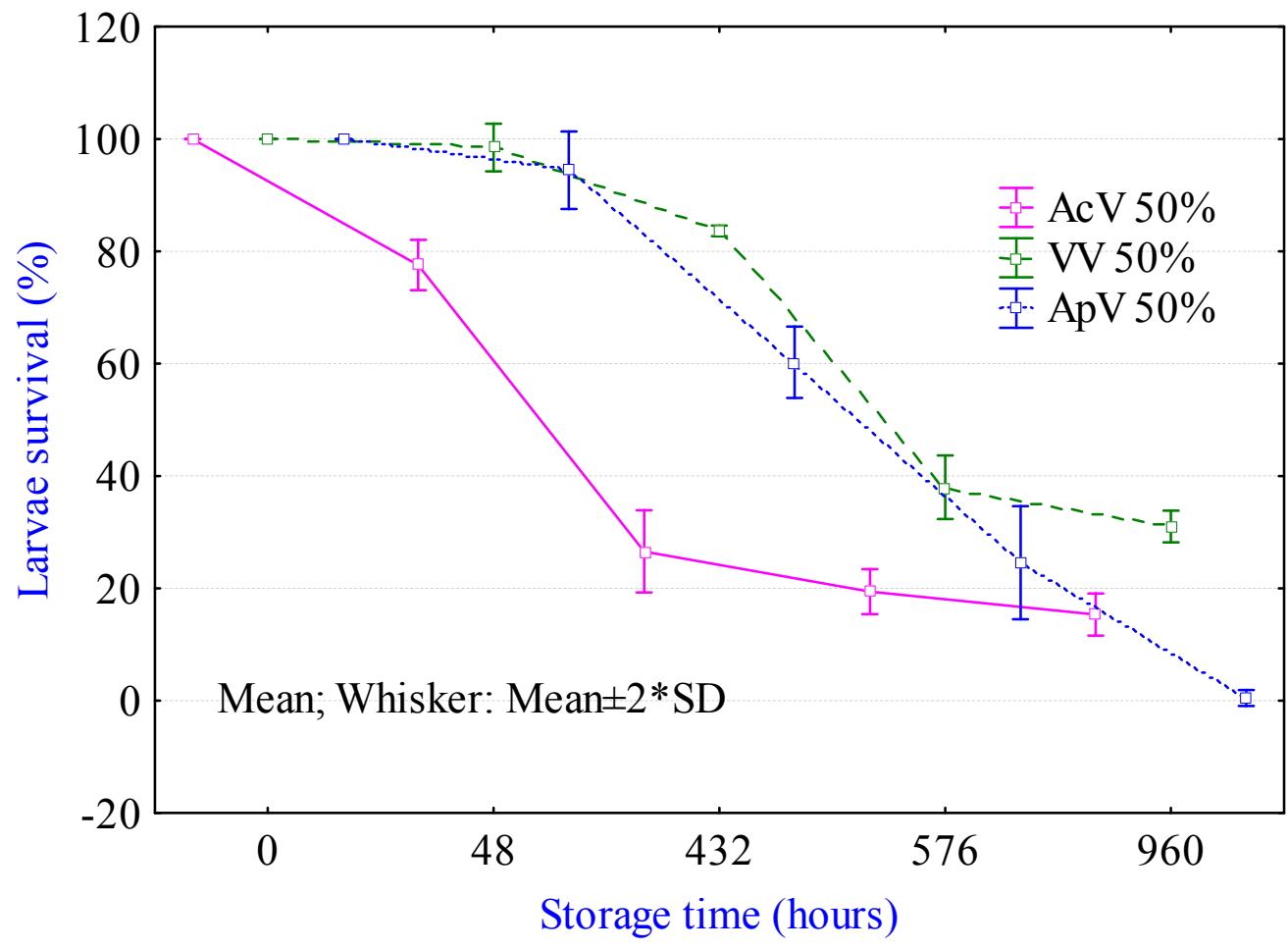

Figure 4. Survival of Anisakis spp. larvae exposed directly to water:vinegar mixtures (ratio 1:1): alcohol (AcV 50\%), wine (VV 50\%), and apple vinegar (ApV 50\%).

Survival of Anisakis spp. larvae after direct exposure to alcohol (9\% acetic acid), wine (6\% acetic acid), and apple vinegar (4\% acetic acid), and their solutions with water are shown in Figures 3 and 4 . 
In intact alcohol vinegar, larvae were killed under less than $48 \mathrm{~h}$, while in the solution with water their resistance was prolonged to almost 40 days.

\subsection{Viability of Larvae During Non-Thermal Processing in Fish Fillets}

This study investigated the survival of Anisakis spp. during two marinating processes and dry salting of anchovies and the results are presented in Table 1. In all three investigated processes, the recovery of the larva inserted into the fillets was $100 \%$. Some larvae were able to leave the pockets in the fillets and were found between the fillets or in the processing media, in this case marinating baths. In the marinated fillets, the $\mathrm{pH}$ was similar but obtained by different media (lemon juice $+5 \%$ acetic acid vs. white wine vinegar) and the $\mathrm{NaCl}$ content differed between the samples (Table 1). The $\mathrm{pH}$ value and $\mathrm{NaCl}$ content of dry-salted fillets were significantly higher and in these conditions, there were no live larvae after the maturation process. The $\mathrm{pH}$ value did not influence the viability of larvae; however, the $\mathrm{NaCl}$ content did. Also, the survival of the larvae in fillets was higher than when larvae were directly exposed to the processing media used for marinating; thus, we can conclude that the fillet provided certain protection for larvae against the combined effect of acid and salt during the marinating processes (Figure 5A). Sánchez-Monsalvez et al. obtained similar results and stated that the survival of the larvae directly exposed to a similar acetic acid and salt concentration (10\% acetic acid, 3\% salt) did not coincide with that seen when they were placed under the fish musculature [26]. On the contrary, larvae survived for much longer. In herring filets, marinated in brine with $6.3 \%$ salt and $3.7 \%$ acetic acid, $A$. simplex larvae survived for 28 days [25]. In dry-salted fillets, the $\mathrm{NaCl}$ content was $>16 \%$, and although $3 \%$ of the larvae was able to leave the pockets (Figure $5 \mathrm{~B}$ ) at the end of the maturation period (10 days), all larvae were found dead.

European anchovies present a risk of anisakiasis in human populations, outlined when several factors are taken into consideration. Anchovy is a small pelagic fish which is landed in large quantities and presents a moderately high-infected paratenic host, especially in the Adriatic [17,18]; it represents one of the most attractive Mediterranean fisheries products traditionally consumed without thermal preparation, and it is impossible to eviscerate the fish on board or take other similar activities due to the large landings (around 3-5 tons per fishing boat) and the fact that there are no automatic lines for evisceration or filleting of anchovies. Thus, education of fishermen to shock the fish on board, which delays the larval migration from viscera to muscle for several days [22], and the necessity of freezing the fish/product reduces the risk of infection with live larvae. The freezing process and storage in freezers result in denaturation of muscle proteins and marinating of thawed fish presents a challenge with respect to fillet organoleptic properties. Consequently, freezing recommendations are often avoided and products are only visually inspected before consummation. Chemical preservation methods, such as marinating and salting, are most commonly used to inactivate viable anisakid larvae; however, in traditional marinating and salting methods, larvae are killed after several weeks [1,25].

Since European Food Safety Authority (EFSA) stated that many traditional marinating and cold-smoking methods are not sufficient to kill Anisakis larvae, recent research focused on the search for alternative treatments for killing viable parasites in fisheries [1]. Other studies, also reported in EFSA, showed that under industrial production of salted fish, the total necessary time for the parasites to be killed was 20 days, and when a $\mathrm{NaCl}$ concentration of $8-9 \%$ was reached in the muscle, at least 6 weeks was needed to kill the parasite [1]. Successively, Smaldone et al. showed that the double-salting process for fresh cod (Gadus morhua) fillets resulted in a salt concentration of $18.6 \%$ in the fillets, and killed Anisakis larvae in 15 days [27]. This process consisted of brining in $13 \% \mathrm{NaCl}$ solution (at $5{ }^{\circ} \mathrm{C}$ for $24 \mathrm{~h}, 1: 1$ fish-to-brine ratio) and dry salting, followed by three months maturation at $5^{\circ} \mathrm{C}$ by stacking fish and salt in ratio $1: 1$ in alternating layers. 
Table 1. Chemical characteristics and viability of Anisakis spp. larvae during the marinating processes (carpaccio and white vinegar/salt) and dry salting of anchovy.

\begin{tabular}{cccc}
\hline & $\begin{array}{c}\text { Carpaccio } \\
\text { Marinade }\end{array}$ & $\begin{array}{c}\text { White Wine Vinegar } \\
\text { Marinade }\end{array}$ & Dry-Salted Fillets \\
\hline pH of the fillet & $3.94 \pm 0.03$ & $3.82 \pm 0.24$ & $5.78 \pm 0.24$ \\
Salt content in the fillet (\%) & $3.96 \pm 0.24$ & $2.41 \pm 0.24$ & $16.37 \pm 0.67$ \\
Duration of maturation & 7 days at $4{ }^{\circ} \mathrm{C}$ & 7 days at $4-8^{\circ} \mathrm{C}$ & 10 days at $16^{\circ} \mathrm{C}$ \\
Recovered larvae after maturation (\%) & 100 & 100 & 100 \\
Larvae found in the fillet pocket (\%) & $81.0 \pm 2.5$ & $68.0 \pm 2.4$ & $97.0 \pm 2.8$ \\
Larvae found in the fillet outside the pocket (\%) & $6.3 \pm 2.1$ & $2.7 \pm 0.3$ & $3.0 \pm 0.1$ \\
Larvae found in the marinating bath (\%) & $13.2 \pm 3.1$ & $31.4 \pm 4.8$ & - \\
Percentage of live larvae after maturation & $39.1 \pm 7.8$ & $54.3 \pm 4.3$ & 0 \\
Percentage of live larvae after 30 days of storage & $0.3 \pm 0.4$ & $1.6 \pm 8.1$ & $0 *$ \\
Percentage of live larvae after 60 days of storage & 0 & 0 & - \\
\hline
\end{tabular}

* after 20 days.

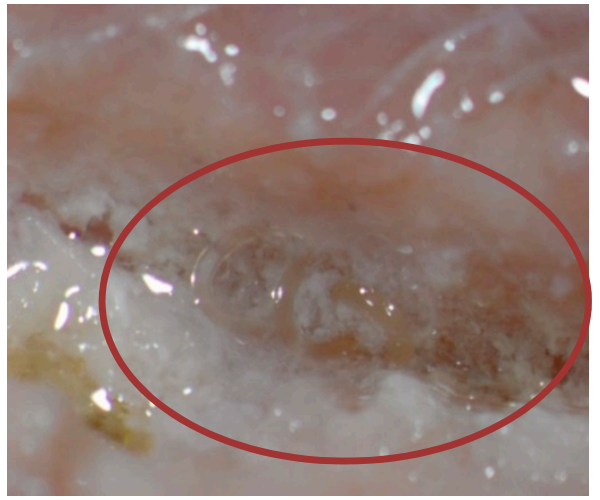

(A)

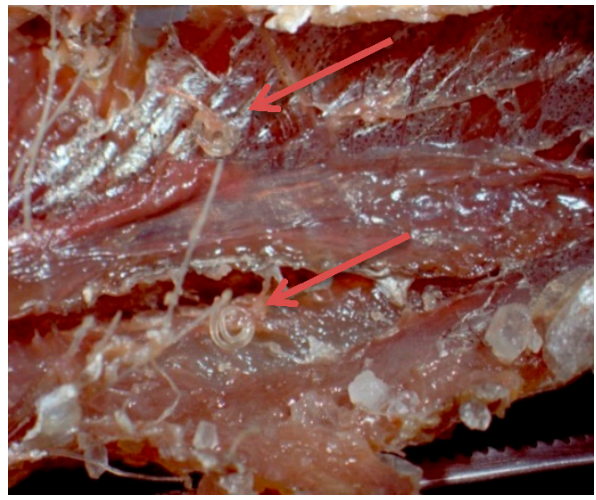

(B)

Figure 5. L3 Anisakis spp. larvae was inserted into the pockets of marinated (A) and dry-salted (B) fish during the maturation period of 7 and 10 days.

\section{Materials and Methods}

A total of 9000 live third-stage (L3) Anisakis spp. larvae were collected from under the visceral serosa of the anchovy's stomach, intestine, gonads, and liver (Figure 6). Fish were caught from Croatian fishing areas in the North and South Adriatic region, iced on board, and transported to the laboratory. In order to remove any excess tissue, larvae were briefly washed in $0.2 \% \mathrm{NaCl}$ solution. Larvae were examined under the stereomicroscope (Olympus, BX51) and morphologically identified as Anisakis spp. based on the presence of mucron and the boring tooth and appearance of the oesophagus and ventriculus. Additionally, a small proportion of larvae were identified as Anisakis pegreffii at the molecular level using a partial mitochondrial cytochrome oxydase 2 DNA sequence, as previously described and reported in Mladineo et al. [17]. 


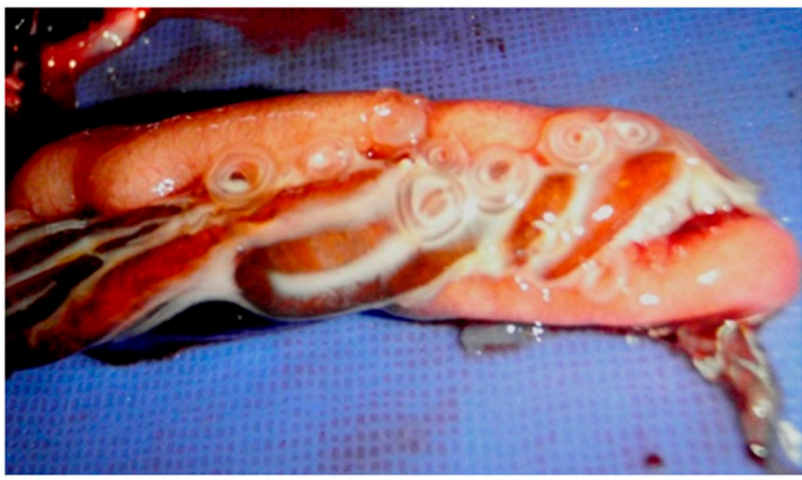

(A)

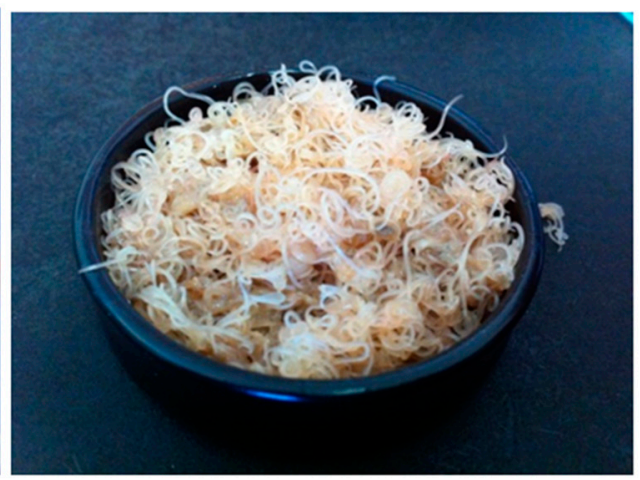

(B)

Figure 6. Live third-stage (L3) Anisakis spp. larvae collected from under the visceral serosa of anchovy (Engraulis encrasicolus) (A) and washed before the experiment (B).

\subsection{Viability Test in Processing Media}

To evaluate L3 larvae viability in different processing media, nematodes were incubated in the following solutions: (i) 5, 10, 15, 20, and $35 \mathrm{~g} \mathrm{NaCl} / 100 \mathrm{~mL}$ water; (ii) $10 \mathrm{~g}$ sugar $/ 100 \mathrm{~mL}$ water; (iii) fresh lemon juice; (iv) lemon juice with addition of 5, 10, and 15\% acetic acid (vol/vol); (v) alcohol, wine, and apple vinegar; (vi) alcohol, wine, and apple vinegar solutions prepared with water in a ratio 1:1. One hundred live L3 larvae were added into Falcon tubes, followed by $200 \mathrm{~mL}$ of prepared solutions (each prepared in triplicate), subsequently closed and kept at $4( \pm 2){ }^{\circ} \mathrm{C}$ (Figure 7). The survival of the larvae was monitored microscopically over incubation time in the processing media. The larvae were considered viable if spontaneous and stimulated movements were observed, while those that showed no movement even when probed with a fine needle were considered and counted as dead following EFSA [1].
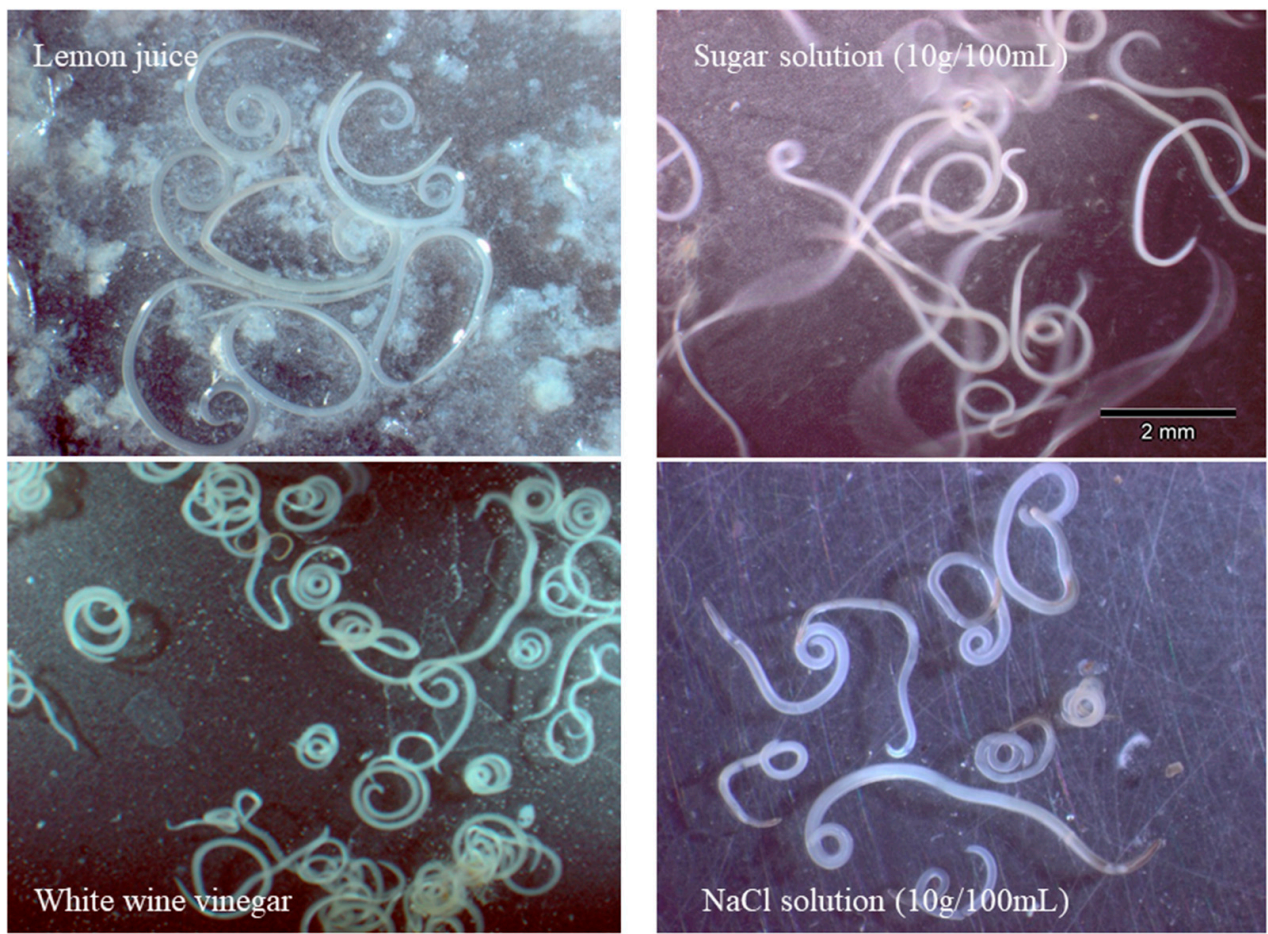

Figure 7. Anisakis spp. larvae exposed directly to (from upper left to right): lemon juice, sugar solution, white wine vinegar, and $\mathrm{NaCl}$ solution. 


\subsection{Viability Test during Non-Thermal Processing}

To evaluate L3 larvae viability in anchovy (E. encrasicolus) fillets during non-thermal processing and the combined effect of processing media (e.g., table lemon juice and $\mathrm{NaCl}$ ), the viability was investigated during the preparation of traditional "carpaccio", white vinegar marinade, and the dry salting process. For the cold-marinating process, fresh anchovies were collected, eviscerated, fileted (butterfly fillets), and thoroughly washed. Six batches, each containing 100 individual fish, were prepared for marinating. Microscopically, at four places on each fillet, a small pocket was incised with a scalper and one L3 Anisakis larvae was inserted into the pocket and sewed in. Three batches were used in the carpaccio marinade process consisting of brining the anchovy fillets in $\mathrm{NaCl}$ solution $20 \mathrm{~g} / 100 \mathrm{~mL}$ for $20 \mathrm{~min}$, followed by marinating in fresh lemon juice with $5 \%$ acetic acid (vol/vol) and olive oil. The other three batches were marinated in white wine vinegar: water solution in ratio 1:1 with $7 \% \mathrm{NaCl}$. The viability of the larvae was noted at the end of the maturation period after seven days at $4 \pm 2{ }^{\circ} \mathrm{C}$ and 22 days at $4-8{ }^{\circ} \mathrm{C}$, for carpaccio and white wine vinegar marinade respectively, and after 30 and 60 days of storage at $4 \pm 2{ }^{\circ} \mathrm{C}$. To investigate the survival of the larvae during the shelf life of the products, an additional six batches of each marinade were prepared following the same procedures, stored at $4 \pm 2{ }^{\circ} \mathrm{C}$ and tested for the viability of larvae after 30 and 60 days. For the dry salting experiment, two batches each containing 100 fresh anchovies were eviscerated and the L3 Anisakis larvae were inserted into four pockets incised at the left and right side of the spine in the middle of the fish. The fish were then laid out flat in alternating layers (13 fish per raw) in standard cans 5/1 with salt interspersed between the layers. At the end, the pressure was applied to push the fish to the edge of the cans. The viability of the larvae was noted at the end of overpressure period after ten days at $16 \pm 2{ }^{\circ} \mathrm{C}$ and after 20 days of maturation. Nematodes were carefully dissected from the fillets, incubated at room temperature in $1 \%$ acetic acid for $24 \mathrm{~h}$, and microscopically inspected for spontaneous and stimulated movements $[1,25]$.

\section{3. $\mathrm{pH}$ and $\mathrm{NaCl}$ Analyses}

Sodium chloride content and $\mathrm{pH}$ were determined in both groups of marinated anchovies and in salted anchovy fillets at the end of maturation period. Sodium chloride $(\mathrm{NaCl})$ content in fish muscle was determined according to AOAC methods [29]. The $\mathrm{pH}$ value of the fish fillet homogenate (fillets were homogenized with distilled water in the ratio 1:10 $(w / v)$ ) was measured using a digital Iskra pH-meter MA 5705 with a combined glass electrode (Iskra Model 0101, Ljubljana, Slovenia). The analyses were done in triplicate.

\section{Conclusions}

Both marinating procedures tested in this study could not destroy Anisakis spp. larvae in short time periods. If not subjected to a freezing regime before production, these products may pose a public health risk of infection with live larvae. Although the larvae survived the direct exposure to different marinating solutions, the infectivity of L3 larvae and their capacity to penetrate tissue after these treatments are questionable and remain to be determined. On the other hand, the dry-salting process is effective in destroying Anisakis spp. larvae, but further effort is needed for detection and successful removal of embedded larvae because allergens from Anisakis may still be present in the products after killing intact worms [3]. Anisakid larvae are widespread and raising consumers' and producers' awareness about their existence in fish is a critical point and effective prevention strategy.

Author Contributions: Conceptualization, V.Š. and Ž.T.; methodology, V.Š.; formal analysis, V.Š.; investigation, V.Š.; writing—original draft preparation, V.Š.; writing—review and editing, Ž.T.; visualization, V.Š.

Funding: This research received no external funding.

Acknowledgments: Authors would like to thank Conex trade d.o.o. for technological support during this study and Ivana Bušelić for constructive comments and help during the preparation of the manuscript. 
Conflicts of Interest: The authors declare no conflict of interest.

\section{References}

1. EFSA Panel on Biological Hazards (BIOHAZ). Scientifc Opinion on risk assessment of parasites in fshery products. EFSA J. 2010, 8, 1543. [CrossRef]

2. van Thiel, P.; van Houten, H. The localization of the herringworm Anisakis marina in-and outside the human gastro-intestinal wall (with a description of the characteristics of its larval and juvenile stages). Trop. Geogr. Med. 1967, 19, 56-62. [PubMed]

3. Audicana, M.T.; Kennedy, M.W. Anisakis simplex: From obscure infectious worm to inducer of immune hypersensitivity. Clin. Microbiol. Rev. 2008, 21, 360-379. [CrossRef] [PubMed]

4. Bao, M.; Pierce, G.J.; Pascual, S.; González-Munõz, M.; Mattiucci, S.; Mladineo, I.; Cipriani, P.; Bušelić, I.; Strachan, N.J.C. Assessing the risk of an emerging zoonosis of worldwide concern: Anisakiasis. Sci. Rep. 2017, 7, 43699. [CrossRef] [PubMed]

5. Guardone, L.; Armani, A.; Nucera, D.; Costanzo, F.; Mattiucci, S.; Bruschi, F. Human anisakiasis in Italy: A retrospective epidemiological study over two decades. Parasite 2018, 25, 41. [CrossRef] [PubMed]

6. Mattiucci, S.; Cipriani, P.; Levsen, A.; Paoletti, M.; Nascetti, G. Molecular Epidemiology of Anisakis and Anisakiasis: An Ecological and Evolutionary Road Map. Adv. Parasitol. 2018, 99, 93-263. [PubMed]

7. Cavallero, S.; Martini, A.; Migliara, G.; De Vito, C.; Iavicoli, S.; D'Amelio, S. Anisakiasis in Italy: Analysis of hospital discharge records in the years 2005-2015. PLoS ONE 2018, 13, e0208772. [CrossRef]

8. Bouwknegt, M.; Devleesschauwer, B.; Graham, H.; Robertson, L.J.; van der Giessen, J.W.; the Euro-FBP workshop participants. Prioritisation of food-borne parasites in Europe, 2016. Eurosurveillance 2018, 23, 17-00161. [CrossRef]

9. Broglia, A.; Kapel, C. Changing dietary habits in a changing world: Emerging drivers for the transmission of foodborne parasitic zoonoses. Vet. Parasitol. 2011, 182, 2-13. [CrossRef]

10. Hochberg, N.S.; Hamer, D.H. Anisakidosis: Perils of the Deep. Clin. Infect. Dis. 2010, 51, 806-812. [CrossRef]

11. Arizono, N.; Yamada, M.; Tegoshi, T.; Yoshikawa, M. Anisakis simplex sensu stricto and Anisakis pegreffii: Biological characteristics and pathogenetic potential in human anisakiasis. Foodborne Pathog. Dis. 2012, 9, 517-521. [CrossRef] [PubMed]

12. del Carmen Romero, M.; Valero, A.; Navarro-Moll, M.C.; Martín-Sánchez, J. Experimental comparison of pathogenic potential of two sibling species Anisakis simplex s.s. and Anisakis pegreffii in Wistar rat. Trop. Med. Int. Health 2013, 18, 979-984. [CrossRef]

13. Jeon, C.H.; Kim, J.H. Pathogenic Potential of Two Sibling Species, Anisakis simplex (s. s.) and Anisakis pegreffii (Nematoda: Anisakidae): In Vitro and In Vivo Studies. Biomed. Res. Int. 2015, 2015, 1-9. [CrossRef] [PubMed]

14. Šimat, V.; Bogdanović, T. Seasonal changes in proximate composition of anchovy (Engraulis encrasicolus, L.) from the central Adriatic. Acta Adriat. 2012, 53, 125-132.

15. European Commission. Regulation of the European Parliament and of the Council (29 April 2004). Laying down specific hygiene rules for the hygiene of foodstuffs, 853/2004/EC. Off. J. Eur. Union 2004, L 139, 55-206.

16. European Commission. Regulation of the European Parliament and of the Council (8 December 2011) amending Annex III to Regulation (EC) No 853/2004 of the European Parliament and of the Council as regards the treatment to kill viable parasites in fishery products for human cons. Off. J. Eur. Union 2011, L 327, 39-41.

17. Mladineo, I.; Šimat, V.; Miletić, J.; Beck, R.; Poljak, V. Molecular identification and population dynamic of Anisakis pegreffii (Nematoda: Anisakidae Dujardin, 1845) isolated from the European anchovy (Engraulis encrasicolus L.) in the Adriatic Sea. Int. J. Food Microbiol. 2012, 157, 224-229. [CrossRef] [PubMed]

18. Cipriani, P.; Sbaraglia, G.L.; Palomba, M.; Giulietti, L.; Bellisario, B.; Bušelić, I.; Mladineo, I.; Cheleschi, R.; Nascetti, G.; Mattiucci, S. Anisakis pegreffii (Nematoda: Anisakidae) in European anchovy Engraulis encrasicolus from the Mediterranean Sea: Fishing ground as a predictor of parasite distribution. Fish. Res. 2018, 202, 59-68. [CrossRef]

19. AAITO-IFIACI Anisakis Consortium. Anisakis hypersensitivity in Italy: Prevalence and clinical features: A multicenter study. Allergy 2011, 66, 1563-1569. [CrossRef] 
20. Fumarola, L.; Monno, R.; Ierardi, E.; Rizzo, G.; Giannelli, G.; Lalle, M.; Pozio, E. Anisakis pegreffi etiological agent of gastric infections in two Italian women. Foodborne Pathog. Dis. 2009, 6, 1157-1159. [CrossRef]

21. Mladineo, I.; Poljak, V.; Martínez-Sernández, V.; Ubeira, F.M. Anti-Anisakis IgE seroprevalence in the healthy Croatian coastal population and associated risk factors. PLoS Negl. Trop. Dis. 2014, 8, e2673. [CrossRef]

22. Šimat, V.; Miletić, J.; Bogdanović, T.; Poljak, V.; Mladineo, I. Role of biogenic amines in the post-mortem migration of Anisakis pegreffii (Nematoda: Anisakidae Dujardin, 1845) larvae into fish fillets. Int. J. Food Microbiol. 2015, 214, 179-186. [CrossRef]

23. Rello, F.J.; Adroher, F.J.; Benítez, R.; Valero, A. The fishing area as a possible indicator of the infection by anisakids in anchovies (Engraulis encrasicolus) from southwestern Europe. Int. J. Food Microbiol. 2009, 129, 277-281. [CrossRef]

24. Guardone, L.; Nucera, D.; Lodola, L.B.; Tinacci, L.; Acutis, P.L.; Guidi, A.; Armani, A. Anisakis spp. larvae in different kinds of ready to eat products made of anchovies (Engraulis encrasicolus) sold in Italian supermarkets. Int. J. Food Microbiol. 2018, 268, 10-18. [CrossRef]

25. Karl, H.; Roepstorff, A.; Huss, H.H.; Bloemsma, B. Survival of Anisakis larvae in marinated herring fillets. Int. J. Food Sci. Technol. 1995, 29, 661-670. [CrossRef]

26. Sánchez-Monsalvez, I.; de Armas-Serra, C.; Martínez, J.; Dorado, M.; Sánchez, A.; Rodríguez-Caabeiro, F. A new procedure for marinating fresh anchovies and ensuring the rapid destruction of Anisakis larvae. J. Food Prot. 2005, 68, 1066-1072. [CrossRef]

27. Smaldone, G.; Marrone, R.; Palma, G.; Sarnelli, P.; Anastasio, A. Preliminary study on the inactivation of anisakid larvae in baccalà prepared according to traditional methods. Ital. J. Food Saf. 2017, 6, 6964. [CrossRef]

28. Mladineo, I.; Bušelić, I.; Hrabar, J.; Vrbatović, A.; Radonić, I. Population parameters and mito-nuclear mosaicism of Anisakis spp. in the Adriatic Sea. Mol. Biochem. Parasitol. 2017, 212, 46-54. [CrossRef]

29. AOAC. Official Methods of Analysis, 17th ed.; The Association of Official Analytical Chemists: Gaithersburg, MD, USA, 2000.

(C) 2019 by the authors. Licensee MDPI, Basel, Switzerland. This article is an open access article distributed under the terms and conditions of the Creative Commons Attribution (CC BY) license (http://creativecommons.org/licenses/by/4.0/). 